Article

\title{
The Green Revolution in the World's Religions: Indonesian Examples in International Comparison
}

\section{Thomas A. Reuter}

Asia Institute, University of Melbourne, Vic 3010, Australia; E-Mail: treuter@unimelb.edu.au; Tel.: +61-3-9035-4281

Academic Editor: Michael S. Hogue

Received: 2 June 2015 / Accepted: 8 October 2015 / Published: 16 October 2015

\begin{abstract}
Similar to progressive political movements, the programs of many religious and spiritual groups today are converging around a shared commitment to address the impending global ecological crisis. The paper explores this convergence by looking at the impact of environmentalist thought on religious discourses in modern Indonesia, the author's primary research area, and comparing the findings to similar trends elsewhere. The research shows that the environmental movement is causing a transformation in how people understand the character and practical relevance of religion and spirituality today, in Indonesia and beyond. For some eco-spiritual groups, a heightened environmental awareness has become the central tenet of their monistic religious cosmology. The more significant phenomenon, however, is a socially much broader shift toward more science-friendly and contemporary religious cosmologies within the mainstream of major world religions. Islam and Christianity now officially accept that other forms of life have a right to exist and that humanity has a custodial obligation to protect nature. This new outlook rectifies the previous tendency within dualist religions to view nature as vastly inferior and servile to human interests. It simultaneously is a rejection of materialist-scientific cosmologies widely prevalent in late modern consumer societies, which deny any notion of the sacred. This trend in the world's religions toward a re-evaluation of the cosmological status of humanity in relation to nature and the sacred, I argue, will enhance the prospects of the global environmental movement's campaign for environmental sustainability.
\end{abstract}

Keywords: religious change; ecology; Indonesia; eco-spirituality; anthropology 


\section{Introduction}

The current epoch in the history of life on Earth has come to be known as the Anthropocene, the age when humans became a truly world-transforming species. The world-transforming powers we have acquired through the development of technology make it imperative for us to develop also our capacity for self-reflection. We can easily fall victim to habitual activity patterns that are destructive of life unless we raise awareness, and already, there is overwhelming evidence that our activity patterns are triggering a mass extinction event and leaving us on the brink of a multidimensional and global ecological crisis [1]. This crisis highlights the interdependent or "ecological" character of our existence and, hence, the vital need for a radical transformation in how we understand our place as human beings within the natural world. A more aware, caring and responsible attitude toward nature would now seem mandatory to safeguard our own survival in the near to medium term, and more so the welfare of future generations. What role will religions play in this process of transformation?

Human self-understanding is shaped by cultural assumptions. The most fundamental assumptions human beings hold are enshrined in cosmologies, which can be religious, or secular, or a combination of both. Cosmologies are herein defined as explicit or implicit models for understanding our place as human beings within the world and, hence, for defining our sense of the purpose in life and our core values. If we wish to transform our self-understanding toward greater ecological awareness, we thus must begin with a critical examination of the cosmological frameworks of our contemporary societies, before rushing to change derivative value and status systems. This is not an easy process, because major cosmological corrections shake up our most fundamental and cherished ideas about the world, as well as upsetting derivative discourses and patterns of socio-political privilege. Cultural change resistance thus arises with some regularity in times of crisis, when the cosmological foundations of the prevailing culture typically become subject to critical scrutiny [2,3].

Even though local responses to the environmental crisis do vary, depending on the unique cosmological starting position of each society, change resistance is a common obstacle. There are two main causes for change resistance-cosmological and socio-political-that together explain why, despite dire warnings by natural scientists about the effects of climate change and other environmental threats, the response to this challenge has been slow and hesitant. Climate scientists have recognized this and have begun to call upon the social sciences for assistance, so as to better understand and address this systemic change resistance [4]. While there have been many efforts to show that socio-political resistance flows from a desire to protect entrenched privilege, in the fossil fuel industry for example [5], there has been less public attention directed at the role of cosmological change resistance, on which this article is focused.

Fear of innovation in cosmological principles can make it very difficult to even begin to think in the novel ways mandated by the advent of the global ecological crisis. Given that people dwell in interpretive worlds, it can seem to them that 'the world' shall end if they allow any cosmological adjustment to take place. Note that such fear-based resistance is not just relevant for religious cosmologies, but also applies to prevailing secular cosmologies, such as consumer society hedonism. The specific focus in this article, however, will be on the adjustments now taking place in religious cosmologies, using the rise of eco-Islam in Indonesia as the primary example. 
The traditional cosmological models of Islam and Christianity are both based on a principle of transcendentalist dualism, envisaging a divine creator and a human soul as non-material (spiritual) subjects existing separately from material nature and being of superior value. This transcendental dualism has been identified in popular literature as a deep-seated obstacle to enhanced ecological awareness and responsibility within these traditions [6]. While such cosmological obstacles may have delayed the now desperately needed process of human self-reflection and transformation within these religions, the findings detailed below do show that significant cosmological change is now occurring.

A "green revolution" has begun to unfold, transforming the cosmological assumptions of religions and spiritualities worldwide [7]. This "greening" process has been studied by social scientists for some time now, for example by Mary Evelyn Tucker and her husband John Grim, who organised a now legendary series of ten conferences on "World Religions and Ecology" at the Centre for the Study of World Religions at Harvard (1995-1998) and later established the Forum on Religion and Ecology at Yale University [8] with the aim of studying this historic encounter between religion and ecology. In this paper, I provide an update on this process of change, with a special focus on Indonesia. While it may long have been a "quiet revolution" ([9], title), restricted to the progressive margins of the religious spectrum, a cosmological reorientation is now gathering pace and transforming religions not only in the West, but also in Asia and elsewhere. Similar to contemporary political movements [10], progressive religious and spiritual groups everywhere appear to be converging around a shared commitment to meet the challenges arising from the global ecological crisis. The public today all but expects religious teachers and organizations to integrate an ethical commitment to sustainability into their theology and practice and to work collaboratively with other faith traditions.

Some progressive eco-spiritual groups have fully embraced the new environmental consciousness and made (deep) ecology the central principle of their religious cosmology, whereby nature is regarded as the embodiment of the sacred whole and humanity as holding at best a position of primes inter pares compared to other species $[11,12]$. These new eco-religions argue for a re-enchantment of nature and the material world, for example through new interpretations of animism, and we have seen the effects thereof also within social science [13-15]. The notion that the natural world is alive and sentient answers the need for a new cosmology that holds nature to be sacrosanct and, hence, inviolable. This progressive fringe of the contemporary spectrum of religions, though it is relatively small if we only count active followers of eco-spiritual groups, is the vanguard of a wider movement, has a large number of sympathizers among nominal followers of mainstream religions, and thus exerts some pressure on the leaders of the latter.

The broader and socially more significant phenomenon, however, is a moderate shift toward a more eco-friendly religious cosmology in the major world religions, including Islam and Christianity. This shift reflects external pressures, but it is also the result of a genuine, ecology-inspired self-critique. Mainstream religions often combine this with a critique of the wholesale dismissal of the sacred that is reflected in the attitudes of late modern, secular consumer societies, which they like to portray as the root cause of callousness toward the environment. In short, this reform is not just a mea culpa but also an active assertion of the renewed relevance and truth of religion in a context of ecological crisis.

The advent of a cosmological "green shift" described in this article provides some reason for hope that a fundamental reorientation is at last taking place, a revolt against rampant, nature-denigrating transcendentalism, while at the same time rejecting the cynicism and underlying despair of late modern 
consumer society, whose ethos of nihilist materialism has dismissed the very notion of Spirit or Soul and encouraged a view of life as devoid of intrinsic value and purpose. The emerging consensus within the mainstream Abrahamic religions, I will argue, is based on the adoption of a much more positive attitude toward nature. Nature is now upheld as a part of divine revelation and a living subject deserving of human custodial care, while rampant anthropocentrism and destructiveness toward nature are described as sinful and suicidal. Nature is still seen as "God's creation" and distinct from humanity in that it lacks an immortal soul (anima), but like humans, it is now attributed with intrinsic value and, in the case of other life forms, with sentience and an inherent dignity.

The pathway to this new position has been different in Indonesian Islam compared to Christianity in the West, with considerably less resistance to the reception of ecological thought. I will begin by exploring an ecological shift in contemporary Islam as it can be observed in Indonesia, where I have conducted continuous ethnographic research on culture and religion over the last 25 years. I will then briefly compare Indonesian trends with some similar developments observable in other Muslim countries, among Christian denominations in the West and in the global interfaith movement. The results of this comparison suggest that the environmental crisis is the driving force behind a fundamental shift in how people worldwide understand their religions and spiritualities today. This does not mean that religions are simply passive recipients of an external influence. For many faith communities, their active involvement in the project of facilitating a new human self-awareness, through a green shift in religious and spiritual thinking, offers an opportunity to demonstrate the ongoing relevance of the concept of sacredness to contemporary society.

\section{Ecology and Contemporary Religion in Indonesia}

The re-evaluation of the cosmological status of nature within religions and spiritualities, I argue, is an important support and perhaps even an indispensable prerequisite for the success of the global environmental movement. There is a need to track such developments, and much has indeed been written about the prospects for such a transformation in the Christian majority societies of Europe and North America. The global ecological crisis and an associated demand for "greener" religions, however, is also very much felt in developing countries, wherein other world religions and local traditions may predominate, providing a rather different cosmological starting position. A pertinent example is Indonesia, where the author has been conducting long-term research on religious change, specifically on the islands of Bali, Java and Borneo. The following account seeks to illustrate how Indonesia's green shift is taking shape and to analyse comparatively to what extent its pathway differs from our experience in the West.

The overwhelming majority of Indonesians profess to be of the Islamic faith, and the "greening" of Islam thus will be the most important consideration here (there is some irony in this phrasing because Islam is traditionally associated with the colour green). In some regions of Indonesia, however, Hindus, Protestants or Catholics form the majority of the local population. More importantly, their formal confession to Islam or one of the other major world religions, which is mandatory for all citizens under Indonesian law, does not prevent individuals and ethnic groups throughout Indonesia from identifying strongly, and sometimes more strongly, with their diverse local, indigenous religious traditions. 
The content of these local religions is officially classified within state discourses as merely "cultural" (budaya), "customary" (adat) or a matter of private "belief" (kepercayaan). While this reflects the prevalent state policy on religion, which favours monotheism and the big traditions, countless ethnographic reports have shown that indigenous religion remains very important in most parts of Indonesia and is indeed experiencing a revival [16-18]. The history of smaller, local religious traditions is complex. In the central part of Indonesia, these indigenous traditions merged with Indian religions over a period of more than a millennium, from the 5th century onward. In the outer islands, indigenous local traditions remained largely untouched by foreign influence until the arrival of Islam and Christianity in the archipelago. These traditions were typical of the religions of Austronesian-speaking populations throughout Southeast Asia and the Pacific. The main cosmological features of Austronesian religions include a form of animism (i.e., the belief that humans and other elements of nature all have a soul, not just humans) and ancestor veneration, whereby ancestors are associated with the sacred source of life. Similar to Hinduism, the indigenous religious traditions of Austronesian-speaking societies are internally very diverse. They are not monotheistic, and their cosmologies do not postulate a sharp dualism between a spiritual creator and material creation. They thus view nature and place-specific ancestors as the sacred source of all life and imbued with profound spiritual significance. Local traditions generally involve veneration of specific ancestors and local deities, some more abstract deities that are personified forces of nature or (on the central islands) personal deities that have been adopted from the Hindu pantheon. Until today, it is Indonesia's indigenous religious traditions that define the spiritual geography of the countryside, which is dotted with countless sacred (keramat) sites that are linked together through mythical narratives of origin $[19,20]$.

What this means, for our present purpose, is that any cosmological shift toward a "greening" of Islam or Christianity in Indonesia can also be understood as a return, in part, to age-old indigenous or Hindu-Buddhist religious attitudes toward a sacred natural world. Such nature-friendly cosmologies were diminished but never wholly abandoned following the rise of Islam as the paramount state religion in Java, some five hundred years ago, or with the later spread of Catholicism and Protestantism in other parts of Indonesia in the wake of Portuguese and Dutch colonialism.

Such a "revivalist interpretation" of Indonesian eco-spirituality will not be entirely unfamiliar to Western readers. The same interpretation can also be applied to a lesser extent to Europe, where a nature-embracing "neo-paganism" based on a revival of indigenous European religions is receiving renewed interest and presents itself very much as a form of eco-spirituality [10]. In Indonesia, moreover, the cosmological influence of indigenous religions is much greater than it is in Europe due to the greater continuity of these traditions in Indonesia. By the same token, there is also more political tension between indigenous and introduced religions in Indonesia.

This situation rather complicates the interpretation of contemporary eco-religious trends in Indonesia. On the one hand, many supporters of indigenous religions (with or without Hindu influence) have specifically told me that they see their own traditions as fundamentally more eco-friendly than Islam and Christianity, which they say lack respect for the sacredness of nature. These arguments were raised to show that indigenous religion has continued value and relevance and is not backward (as their opponent would have it), but "more progressive" than the Abrahamic religions.

Such claims are not often publicised, however, and hence, they have not generated enough political heat to invite a counter reaction from Islam. Indeed, I have been unable to find any evidence of 
Indonesian Muslim scholars or clerics voicing any fear that eco-spirituality could serve as a cover for the reassertion of indigenous or Hindu religious beliefs. Drawing on the works of international Muslim scholars, like Seyyed Hossein Nasr, Mawil Izzie Dien, Ziauddin Sardar, S. Parvez Manzoor, Fazlun Khalid and others [21-26], Indonesian Muslim scholars, rather, are very confident and proud to conclude that a certain variant of eco-spirituality is legitimately and can be proudly claimed as an integral part of Islam with a strong scriptural pedigree.

In interpreting the rise of ecological thought in Indonesian Islam, another important question is: what is the source of innovation and, hence, the causal direction of this social process? Public debates led by Muslim theologians and clerics certainly have an impact in Indonesia, as elsewhere, but popular trends also have their own dynamic and can exert pressure on clerics and scholars. Within Islam, this bottom-up movement of ideas is particularly important, because Muslim clerics do not form a single, unified organisation with a supreme leader, certainly not in Indonesia, and hence, no person or organisation has supreme authority in the interpretation of scriptures with regard to contemporary issues. While some proclamations (fatwa) of some clerics do exert significant influence, others do not, depending significantly on the persuasiveness of their argument and not just on their social position [27]. The Muslim public is thus able to be selective in what it receives from religious experts and is by no means a passive recipient of either neo-conservative or progressive religious ideas. Given the fact that popular Muslim clerics regularly pick up on contemporary issues in their sermons, it is probably fair to assume that ecological thought has become one of the trendiest topics in these sermons as a consequence of a shift in public awareness. Rising popular ecological awareness is the driving force.

What surprised me most is that my research did not uncover much evidence of resistance to ecological thought from clerics or ordinary Muslims. Generally, the prospect of an impending ecological crisis is well accepted, and action to avert this crisis is now being depicted not only as necessary but also as a religious duty. One explanation for this open reception is that environmentalists have not problematized Islam in Indonesia in the same way that mainstream Christianity has been challenged in the West. The kind of "deep ecology" that is familiar to many people in the West, and was first advocated by Arne Næss [28], is also not yet well known in Indonesia. Deep ecology has issued a strong call for fundamental cosmological change and has directly criticised the objectification of "soul-less" nature in Christian cosmologies [6]. Official acceptance of such a deeper cosmological shift is hardly possible within Islam or Christianity, and I certainly have seen no evidence for it in Indonesia. Such a deeper ecological shift may nonetheless be attractive to many individual Indonesian Muslims, especially those who are heavily influenced by resonant indigenous traditions.

Most Indonesian Muslims tend to accept ecology as an uncontroversial and fairly self-evident scientific idea, indicating a condition of human interdependence within nature. The urgent need for political action is also widely seen as self-evident, given that most Indonesians have some knowledge of the devastation of tropical forest environments on Sumatra and Borneo at the hands of the mining and palm oil industries [29] and of the extreme environmental pollution issues now plaguing the capital Jakarta and other urban areas.

What controversy there is around ecological questions arises from industry resistance to calls for better environmental protection and sustainable resource management and from the regular failure of corrupt state officials to implement existing policy and legislation on nature protection. Religious and 
environmentalist groups tend to be on the same side of these conflicts and often collaborate. Islamic leaders (ulama) in Kalimantan, for example, were criticised by extractive industries when they issued a fatwa declaring the environmental destruction of the island's forest as haram (forbidden by Islam) [30], while environmentalists applauded and defended them.

For many of the young Indonesian Muslims I have interviewed, to promote or actively engage with environmental groups is a very safe way of projecting a self-image of being a progressive, contemporary and open-minded person. This explains, for example, why a recent article and blog, wherein leaders of WALHI (Wahana Lingkungan Hidup Indonesia, Indonesia's equivalent of Friends of the Earth) loudly called upon Muslim individuals and organisations to help fight environmental destruction "as a matter of religious duty" ([31], p. 1), did not receive one single negative comment, notwithstanding the fact that Indonesia has a sizeable contingent of religious conservatives. Conversely, while some ecological writers do criticise conservatism in Indonesian Islam, suggesting that conservatism deprives Islam of the opportunity to contribute to a solution to the ecological crisis and similar issues, this criticism is directed at a lack of interest in activism and not at Islamic cosmology. Syafur, for example, argues that:

"There has to be a serious and continuous effort to understand [the] fundamental and functional meaning of formal rituals of Islam, in such a way that Islam supports not only Theo-centric but also socio-economic concerns. Once Islam is shackled by its routines and finds no alternative interpretation of its rituals, there hardly is hope of important contributions made by Islamic scholars to cope with ecological and global crises" ([32], p. 44).

Islamic scholars generally agree with this point of view and thus are eager to demonstrate that ecology is intrinsic to Islam, e.g., [33]. Some have gone so far as to describe the Prophet Muhammad as an environmentalist avant la lettre [34]. While a number of passages in the Qur'an, similar to the Bible, imply that mankind is the pinnacle of creation (ashraf al-makhlouqat) and is given dominion over animals and nature, many other passages do support this claim to ecological credentials. These passages evoke the idea of human custodianship (khalifah) and responsibility for maintaining a balance (mizan) between the utilisation and the protection of nature (protection, for example, in zones designated as harim). Such nature-friendly passages in the scriptures are frequently cited by Indonesian eco-Muslims today. For example, the popular Indonesian blog, "Magazine on Islam and Environment" (Makalah Islam dan Lingkungan), has posted an extensive collection of scriptural quotes on ecology [35]. One favourite scriptural passage, "even when doomsday comes, if someone has a palm shoot in his hand, he should plant it" ([36], p. 1), has become so popular, it now serves as an inspirational quote frequently seen on t-shirts [37].

There are also concerted efforts under way to incorporate ecology systematically into Islamic education. A number of Islamic ecological boarding schools (eco-pesantren) have been established in West Java for this purpose, such as Pesantren Al-Ittifaq in Ciwidey [38] and Pesantren Darul Ulum Lido near Bogor [39]. A recent popular post on Vimeo under the heading "Green Islam in Indonesia," meanwhile, provides a collection of thirty-eight documentary videos on the topic of eco-Islamic education, including numerous interviews with Muslim teachers, and also lists numerous eco-education projects in Islamic schools as inspirational examples [40]. 
This broadly-based and accelerating trend toward a greening of Islam in Indonesia is not an isolated phenomenon. Recent international events illustrate the wider significance of ecological issues in contemporary Islam, notably the global summit on 'Islam and the Environment' in Dubai in 2013. The organisers of this historic state that:

"The environment lies at the core of the Islamic faith, and the underlying principal that forms the foundation of the Prophet Mohammed's [...] holistic environmental vision is the belief in the interdependency between all natural elements, and the premise that if humans abuse or exhaust one element, the natural world as a whole will suffer" [41].

In summary, Indonesian Islam, and perhaps Islam more generally, is showing a remarkable ability and eagerness to accommodate and indeed assimilate ecological thought. In part this may be explainable in theological terms, insofar as Islam has long viewed nature as a form of revelation in its own right and holds humans responsible for its protection. There are also some major cosmological limitations in Islam, however, in that the creator is seen as a transcendental entity and separate from the material world, as he is in Christian cosmology.

The reception of ecological thought by Muslims in countries like Indonesia may also have benefitted from the progress already achieved by ecological campaigners in modifying the thinking of faith traditions prevalent in the developed world, particularly Christianity. This process has set a precedent and provided an incentive for Islam to move more quickly toward accepting the findings of modern ecological science and their spiritual implications. Be that as it may, the thousands of environmental actions organised by Muslim organisations in Indonesia today certainly are a testimony to the enthusiastic reception of ecological thinking in this country's largest faith community.

\section{Evidence of a Wider, Global Trend toward the Greening of Religions}

The brief Indonesian case study presented above now needs to be considered further within the context of an international comparison. For the purpose of this paper, some brief remarks on recent trends and events elsewhere may suffice to show how the Indonesian case fits into a larger picture and also to highlight in what ways its pathway differs.

In Europe and the United States, Christian groups have been working actively toward an integration of their faith with ecological principles at least from the 1970s onward (see, for example, [42]). This project now is no longer confined to highly progressive and relatively marginal eco-enthusiast groups, but is being mainstreamed in a comprehensive fashion. This mainstreaming commenced sooner and has advanced further than in Indonesia, but the gap is small and closing rapidly now.

One area in which a gap is still evident in Indonesia is the relative lack of interfaith cooperation in relation to a shared environmentalist agenda in this country. Such a trend toward interfaith convergence of religious progressives around a shared ecological project is clearly observable in Christian-majority countries. In the U.S., for example, eco-religion is now the subject of a national interfaith alliance, the National Religious Partnership for the Environment, which includes "the U.S. Conference of Catholic Bishops along with its activist arm, the Catholic Climate Covenant, the National Council of Churches USA and its affiliate Creation Justice Ministries, the Jewish Council on Public Affairs and its affiliate the Coalition on the Environment and Jewish Life, and the Evangelical Environmental Network" ([43], 
p. 1). Similar trends toward interfaith convergence can be observed in many other societies and in the internationalist arena. Another interesting example at a national level is the Interfaith Centre for Sustainable Development, in Jaffa, Israel [44]. At the international level, one of the best examples of the global success and convergence of the movement for a "greener" religion is provided by the largest inter-faith gathering on the planet, the World Parliament of Religions, which is organised by the Council for a Parliament of the World's Religions. I was able to attend and study the eco-spirituality-related content of presentations given at the last parliament, which was held in my hometown, Melbourne, in 2009 [45]. I discovered that, if the program content of this parliament is any indication, the impending global environmental crisis is now the most talked about issue among religious traditions worldwide and is producing strong calls for a rethinking of religious cosmological assumptions, as well as our daily practices [46]. In Indonesia the interfaith movement does not have the same degree of public and state support, and hence such mutual encouragement toward environmental action between different faith traditions is still uncommon.

How far ecological thought has transformed Christian cosmologies is an open question and impossible to address comprehensively in a brief article such as this. Nevertheless, some pertinent examples will serve to illustrate what the current state of this transformation process is and whether or not Indonesian Islam has had a less arduous time and followed a more direct pathway to reach a similar degree of accommodation with ecology.

Perhaps the most globally significant recent event indicative of the mainstreaming of ecological principles within Christianity was the publication of an encyclical letter by Pope Francis on the issue of climate change and other environmental challenges in the (European) summer of 2015 [47]. This important statement had drawn much acclaim and some criticism in advance [48], reflecting some of the enduring tensions in the Catholic community around these issues. The encyclical endorses a more progressive official theology of nature within Catholicism, viewing it as a priceless part of God's creation, alongside humans. As was to be expected, the encyclical stops short of recognizing humans outright as creatures of nature, but it does make some overtures to evolution and does attribute sentience and dignity to other (soul-less) life forms. The letter repeatedly employs the rather egalitarian metaphor "our Sister Earth" ([47], p. 1), which is taken from St Francis of Assisi. Pope Francis also makes it very clear that Catholics have a responsibility toward the environment and that theological mistakes were made in the past:

"Faith convictions can offer Christians, and some other believers as well, ample motivation to care for nature [...] Christians in their turn realize that their responsibility within creation, and their duty towards nature and the Creator, are an essential part of their faith" ([47], p. 19). "If a mistaken understanding of our own principles has at times led us to justify mistreating nature, to exercise tyranny over creation, to engage in war, injustice and acts of violence, we believers should acknowledge that by so doing we were not faithful to the treasures of wisdom which we have been called to protect and preserve. Cultural limitations in different eras often affected the perception of these ethical and spiritual treasures, yet by constantly returning to their sources, religions will be better equipped to respond to today's needs" ([47], p. 58). "This allows us to respond to the charge that Judeo-Christian thinking, on the basis of the Genesis account which grants man 
"dominion" over the earth ( $c f$. Gen 1:28), has encouraged the unbridled exploitation of nature by painting him as domineering and destructive by nature. This is not a correct interpretation of the Bible as understood by the Church. Although it is true that we Christians have at times incorrectly interpreted the Scriptures, nowadays we must forcefully reject the notion that our being created in God's image and given dominion over the earth justifies absolute domination over other creatures" ([47], p. 20).

The encyclical has been received well by the scientific community for "engaging remarkably deeply with science" ([49], p. 1). This gives rise to the hope that, while the path towards a full acceptance of ecological thought has been more difficult and slow for Christianity compared to Islam, this may turn out to have been a temporary phenomenon. Looking forward, it seems both religions will fully embrace much of the truth of the ecological perspective on life and will be somewhat transformed thereby. In voicing this hope, I would like to stress that the encyclical's significance must be assessed against the background of the protracted struggle that has preceded it.

For Christian theology generally, the encompassment of ecological thought has not been an easy road, and there is still a wide spectrum of opinions when it comes to the interpretation of the cosmological implications thereof. Even though it retains some vestiges of a traditional spirit-matter dualism, the following quote from Brother Charles Cummings shows that some of the most progressive theologians have come a very long way towards a positive revaluing of nature:

"The spreading ecological crisis demands that we take responsibility for the house we live in, which is this planet where we live side by side with all our neighbours - All other living and non-living creatures. From the matrix of this material cosmos human beings emerged, according to God's plan, many millions of years ago. The second account of creation in Genesis describes in its own way how humanity was formed from the reddish clay of the earth. In some sense the earth is our common mother. The commandment to honour our father and mother can be extended to include our mother earth in all her materiality. Today this maternal earth is nurturing and sustaining each of us in life; some day the same earth will receive back our lifeless bodies and incorporate them once again into the flux of elements and particles that make up the cosmos, until the final resurrection" ([50], p. 3).

More conservative theologians still reject this kind of deep ecology thinking. For example, Reverend Robert Sirico, president of the Acton Institute, claims that such reinterpretations of the canon are heretical:

"In secular times such as ours, perhaps, it is not surprising that strange theories that harken back to the Gnostics and the heresies of the early Christian centuries would come into political currency, even through massive popular movements such as an ill-conceived environmentalism that teaches ideas contrary to orthodoxy. But we make a profound error in attempting to graft those ideas onto orthodox faith, and especially to attempt to do so out of a misplaced desire for strategic advantage in the philosophical battles of our time" ([51], p. 1). 
Such contrary voices are becoming more marginal now, but they do remind us that the cosmological shift involved in the greening of Christianity remains a difficult one, though it may be easy enough to gloss over, if one wishes to do so.

\section{Conclusions}

The mainstreaming of eco-religious thinking in Indonesia is likely to catch up with and perhaps overtake similar developments in the faith communities of many Western societies. The evidence shows that Islam in Indonesia, surprisingly perhaps, does not appear to be as stressed by this "green shift" as Christianity has been and continues to be to some extent. The uptake of environmentalism by Muslim organisations in Indonesia can only be described as enthusiastic.

The strong influence of indigenous traditions of ancestor religion and animism, as well as that of Indic religions may have played a role in this, because these traditional views do not require any cosmological revision to accommodate the idea that nature is sacred and is to be treated with reverence. This may well be a hidden factor in Indonesia, but it is difficult to measure short of conducting an in-depth comparative study and analysis of the relative difficulty or ease of reception of ecology in a wider range of Muslim countries. Two explanatory factors that are more easily identified are, first, that the history of the encounter between ecologists and Muslims in this country has not been marked by any significant acrimony and, second, that the precedent provided by the uptake of ecology by other faiths in advanced industrial societies has provided Indonesian activists with a head start.

The one missing ingredient in Indonesia is a national interfaith alliance for the environment. Some local dialogues have been held to explore this possibility, particularly in areas where Islam is not a majority religion. For example, a recent post on the blog site BaleBengong, entitled "Religion Has a Role in Saving the Environment," illustrates that an interfaith dialogue on the environment is now emerging in Indonesia [52].

More generally, my research suggests that a fundamental shift toward more eco-spiritual cosmologies is indeed taking place around the globe. This shift may eventually culminate in a global interfaith alliance for strong action on the most pressing issue of our times.

\section{Acknowledgements}

The Australian Research Council funded this project.

\section{Conflicts of Interest}

The author declares no conflict of interest.

\section{References and Notes}

1. Thomas A. Reuter. "In Response to a Global Environmental Crisis: How Anthropologists Are Contributing toward Sustainability and Conservation." In Averting a Global Environmental Collapse: The Role of Anthropology and Local Knowledge. Edited by Thomas A. Reuter. London: Cambridge Scholars, 2015, pp. 1-22. 
2. Thomas A. Reuter. "Anthropological Theory and the Alleviation of Anthropogenic Climate Change: Understanding the Cultural Causes of Systemic Change Resistance." World Anthropology Network E-Journal 5 (2010): 5-27. Available online: http://www.ram-wan.net/ documents/05_e_Journal/journal-5/2-reuter.pdf (accessed on 15 October 2015).

3. Jack Harich. "Change resistance as the crux of the environmental sustainability problem." System Dynamics Review (2010): 1-38.

4. Thomas A. Reuter, and Hans Baer. "Anthropological perspectives on climate change and sustainability: Implications for policy and action.” Brief for the United Nations Global Sustainable Development Report 2015, commissioned by IUAES and WCAA. Available online: https://sustainabledevelopment.un.org/content/documents/5834GSDR_brief_anthropology_SD_ba er_reuter_rev.pdf(accessed on 15 October 2015).

5. Suzanne Goldenberg. "Just 90 companies caused two-thirds of man-made global warming emissions." The Guardian (Australia), 21 November 2013. Available online: http://www. theguardian.com/environment/2013/nov/20/90-companies-man-made-global-warming-emissionsclimate-change (accessed on 15 October 2015).

6. Daniel Quinn. Ishmael. New York: Bantam/Turner Books, 1992.

7. Alexander Horstmann, and Thomas A. Reuter. "The Post-Modern Shift." Asian Journal of Social Science 37 (2009): 853-56. Introduction to a special issue on "Reflexive Transformation and Religious Revitalisation: Perspectives from Southeast Asia", edited by the authors.

8. See http://cswr.hds.harvard.edu and http://fore.yale.edu respectively (accessed on 15 October 2015).

9. Leslie E. Sponsel. Spiritual Ecology: The Quiet Revolution. New York: Praeger, 2012.

10. Hans Baer, and Thomas A. Reuter. "The Global Movement for a Safe Climate and Environmental Sustainability." The Australian Journal of Anthropology 22 (2011): 255-56.

11. Bron Taylor. "Earth and Nature-Based Spirituality (Part I): From Deep Ecology to Radical Environmentalism.” Religion 31 (2001): 175-93.

12. Laurel Kearns, and C. Keller. Ecospirit Religions and Philosophies for the Earth. New York: Fordham University Press, 2007.

13. Nurit Bird-David. “Animism Revisited: Personhood, Environment, and Relational Epistemology." Current Anthropology 40 (1999): 67-68.

14. Tim Ingold. "Totemism, Animism and the Depiction of Animals." In The Perception of the Environment: Essays on Livelihood, Dwelling and Skill. London: Routledge, 2000, pp. 112-13.

15. Graham Harvey. Animism: Respecting the Living World. New York: Columbia University Press, 2006, p. 9.

16. Thomas A. Reuter. "Religious and Cultural Revitalization: A Post-Modern Phenomenon?" In Faith in the Future: Understanding the Revitalization of Religions and Cultural Traditions in Asia. Edited by Thomas A. Reuter and Alexander Horstmann. Leiden: Brill, 2013, pp. 1-14.

17. Thomas A. Reuter. Global Trends in Religion and the Reaffirmation of Hindu Identity in Bali. Clayton: Monash Asia Institute Press, 2008.

18. Thomas A. Reuter. "Religion in the Age of Globalization: Emerging Trends, Indonesian Examples." In Flows of Faith: Religious Reach and Community in Asia and the Pacific. Edited by Lenore Manderson, Wendy Smith and Matt Tomlinson. Dordrecht and New York: Springer Publishing Company, 2012. 
19. James J. Fox, and Clifford Sathers, eds. Origins, Ancestry and Alliance: Explorations in Austronesian Ethnography. Canberra: Department of Anthropology, Research School of Pacific and Asian Studies, Australian National University, 1996.

20. Thomas A. Reuter. Custodians of the Sacred Mountains: Culture and Society in the Highlands of Bali. Honolulu: Hawai'i University Press, 2002.

21. Seyyed Hossein Nasr. Religion and the Order of Nature. New York: Oxford University Press, 1996.

22. Mawil Izzi Dien. "Islam and the Environment: Theory and Practice." Journal of Beliefs and Values 18 (1997): 47-57.

23. Ziauddin Sardar. The Touch of Midas: Science, Values and Environment in Islam and the West. Manchester: Manchester University Press, 1984.

24. Ziauddin Sardar. Islamic Futures: The Shape of Ideas to Come. London and New York: Mansell Publishing, 1985.

25. Parvez S. Manzoor. "Environment and Values: The Islamic Perspective." In The Touch of Midas: Science, Values and Environment in Islam and the West. Edited by Ziauddin Sardar. Manchester: Manchester University Press, 1984.

26. Fazlun M. Khalid. "Islam and the Environment." In Encyclopedia of Global Environmental Change, Vol. 5, Social and Economic Dimensions of Global Environmental Change. Edited by Peter Timmermen. Chichester: John Wiley \& Sons, 2002, pp. 332-39.

27. Julian Millie. "Spiritual Meal or Ongoing Project? The Dilemma of Dakwah Oratory." In Expressing Islam: Religious Life and Politics in Indonesia. Edited by Greg Fealy and Sally White. Singapore: ISEAS, 2008, pp. 80-94.

28. Arne Næss. "The Shallow and the Deep, Long-Range Ecology Movement." Inquiry 16 (1973): 95-100.

29. Thomas A. Reuter. "Devastation and Hope in Borneo: Anthropologists' First-Hand Account." The Conversation, 23 May 2011. Available online: http:/theconversation.edu.au/articles/ devastation-and-hope-in-borneo-anthropologists-first-hand-account-2118 (accessed on 15 October 2015).

30. Republika Online. "Perusahaan Abaikan Fatwa Pengrusakan Lingkungan MUI." Available online: http://bola.republika.co.id/berita/nasional/hukum/12/12/19/mfalna-perusahaan-abaikan-fatwapengrusakan-lingkungan-mui (accessed on 15 October 2015).

31. Agung Sasongko. "Walhi: Islam Wajib Lawan Pengrusakan Alam.” Republika Online, 6 April 2015. Available online: http://www.republika.co.id/berita/nasional/umum/15/03/28/nlxemmsoekarwo-minta-iphi-sebarkan-islam-indonesia (accessed on 15 October 2015).

32. M. Syafur. "Perspektif Pelestarian Lingkungan Hidup Dalam Islam." MEDIAGRO_Jurnal ilmu-Ilmu Pertanian 4 (2008): 44-56.

33. Sofyan Anwar Mufid. Islam dan Ekologi Manusia. Jakarta: Nuansa Cendekia, 2010.

34. Bahar Davary. "Islam and Ecology: Southeast Asia, Adat, and the Essence of Keramat." ASIA Network Exchange 20 (2012): 1-11. Available online: http://www.academia.edu/3306968/ Islam_and_Ecology_Southeast_Asia_adat_and_Keramat (accessed on 15 October 2015).

35. Kumpulan Makalah. "Makalah Islam dan Lingkungan." Available online: http://makalahku.blogspot.com.au/2012/08/makalah-islam-dan-lingkungan.html (accessed on 15 October 2015). 
36. Frederik M. Denny. "Islam and Ecology: A Bestowed Trust Inviting Balanced Stewardship." The Forum on Religion and Ecology at Yale. Available online: http://fore.yale.edu/religion/islam/ (accessed on 15 October 2015).

37. Kaos motivasi. "Ku Tanam Pohon Walau besok dunia berakhir." Available online: https://nashclothing.wordpress.com/2010/11/23/ku-tanam-pohon-walau-besok-dunia-berakhir/ (accessed on 15 October 2015).

38. Green Islam in Indonesia. "Akhlak Mulia (music)/Eco-Pesantren in West Java." Available online: https://vimeo.com/37350507 (accessed on 15 October 2015).

39. University of Wisconsin. "TONIGHT: An Interfaith Conversation on Faith and Environmentalism." Available online: http://insideislam.wisc.edu/2012/03/tonight-an-interfaith-conversation-on-faithand-environmentalism/ (accessed on 15 October 2015).

40. Vimeo. "Green Islam in Indonesia." Available online: https://vimeo.com/hijau (accessed on 15 October 2015).

41. Islam and the Environment. "A Global Summit to Spread the Green Message." Available online: http://www.islam-environment.com/Green\%20Message-website\%20summary.pdf (accessed on 15 October 2015).

42. Laurel Kearns. "Saving the Creation: Christian Environmentalism in the United States." Sociology of Religion 57 (1996): 55-70.

43. National Religious Partnership for the Environment. Available online: http://www.nrpe.org (accessed on 15 October 2015).

44. The Interfaith Center for Sustainable Development. Available online: http://www.interfaithsustain. com (accessed on 15 October 2015).

45. Parliament of the World's Religions. "Parliament 2009." Available online: http://www. parliamentofreligions.org//content/parliament-2009 (accessed on 15 October 2015).

46. Thomas A. Reuter. "Faith in the Future: Climate Change at the World Parliament of Religions, Melbourne 2009." The Australian Journal of Anthropology 22 (2011): 260-65.

47. Pope Francis. On Care for Our Common Home: Encyclical Letter Laudato Si' of the Holy Father Francis. Rome: Libreria Editrice Vaticana, 2015.

48. Coral Davenport, and Laurie Goodstein. "Pope Francis Steps up Campaign on Climate Change, to Conservatives' Alarm.” The New York Times, 27 April 2015.

49. Belinda Reyers. "Why the Pope's encyclical is about much more than climate change. Future Earth." Posted online in Agenda, the World Economic Forum's news blog, 19 June 2015. Available online: https://agenda.weforum.org/2015/06/why-the-popes-encyclical-is-about-muchmore-than-climate-change/ (accessed on 15 October 2015).

50. Charles Cummings. "Exploring Eco-Spirituality: Nature invites us to care for the natural world as the Garden of both God and humankind." Patheos, 16 September 2009. Available online: http://www.patheos.com/Resources/Additional-Resources/Exploring-Eco-Spirituality (accessed on 15 October 2015).

51. Robert A. Sirico. "The New Spirituality." Acton Institute for the Study of Religion and Liberty, 1997. Available online: http://www.acton.org/public-policy/environmental-stewardship/ecospirituality/new-spirituality (accessed on 15 October 2015). Also published in The New York Times Magazine, 23 November 1997. 
52. Bale Bengong. "Agama Berperan untuk Menyelamatkan Lingkungan.” Available online: http://www. balebengong.net/kabar-anyar/2015/05/19/agama-berperan-untuk-menyelamatkan-lingkungan.html (accessed on 15 October 2015).

(C) 2015 by the author; licensee MDPI, Basel, Switzerland. This article is an open access article distributed under the terms and conditions of the Creative Commons Attribution license (http://creativecommons.org/licenses/by/4.0/). 